\title{
A ESCOLA COMO ORGANIZAÇÃO COMPLEXA*
}

\author{
Mauricio Tragtenberg ${ }^{1}$
}

RESUMO: O texto examina a constituição histórica dos processos de desenvolvimento do capitalismo a partir do século XVI, com a urbanização e a burocratização das instituições de poder, a ampliação da divisão do trabalho e a introdução da técnica, analisando-os como imperativos da generalização da educação escolar. Integrando as contribuiçóes de clássicos como Weber, Marx, Bourdieu, Lobrot, entre outros, compreende-se o surgimento e a recriaçáo de conceitos e práticas como: disciplina, coerção, trabalho, obediência, hierarquia, conformismo, êxito, nas suas formas contemporâneas, estruturadoras tanto da empresa capitalista como da administraçáo pública. Dessa lógica decorre a crítica das organizaçóes na sociedade atual, entre as quais a escola.

Palavras-chave: Organização. Capitalismo. Escola. Burocracia. Reprodução.

\section{SCHOOL AS A COMPLEX ORGANIZATION}

ABSTRACT: The text explores the historical constitution of the capitalism's development processes from the sixteenth century forward, with the urbanization and bureaucratization of power institutions, the expansion of labor division and the introduction of technique, analyzing them as imperatives of school's education generalization. By gathering contributions by classic authors such as Weber, Marx, Bourdieu, Lobrot and others, we try and understand the emergence and re-creation of concepts and practices such as discipline, coercion, labor, obedience, hierarchy, conformity, success in their contemporary forms, structuring both capitalist enterprises and public administration. From this logic, the critique of organizations in today's society comes up, school included.

Keywords: Organization. Capitalism. School. Bureaucracy. Reproduction.

\footnotetext{
*A Revista Educação \& Sociedade agradece à Fundação Editora UNESP a autorizacão para publicação, em suas versóes impressa e digital, do presente texto do autor Maurício Tragtenberg, parte da obra "Sobre educação, política e sindicalismo", 3. ed. São Paulo: Editora UNESP, 2004. p. 45-69. ${ }^{1}$ Universidade Estadual de Campinas, Faculdade de Educação - Campinas (SP), Brasil. (in memoriam, 1929-1988)

DOI: $10.1590 / E S 0101-73302018191196$
} 


\title{
L'ÉCOLE COMME UNE ORGANISATION COMPLEXE
}

RESUMÉ: Le texte examine la constitution historique du processus de développement du capitalisme depuis le XVIe siècle, notamment l'urbanisation et la bureaucratisation des institutions du pouvoir, la division du travail croissante et la technicisation. L'analyse tient compte de ceux-ci comme impératifs de la généralisation de l'éducation scolaire. En s'appuyant sur les formulations classiques de Weber, Marx, Bourdieu, Lobrot, parmi d'autres, on adresse l'émergence et la reformulation de concepts et pratiques tels que discipline, coercition, travail, obéissance, hiérarchie, conformisme et réussite sous ses formes contemporaines et structurantes de l'entreprise capitaliste aussi bien que de l'administration publique. De cette logique ressortent des critiques adressées auxorganisations de la société actuelle, d'entre autres l'école.

Mots-clés: Organisation. Capitalisme. École. Bureaucratie. Reproduction.

\begin{abstract}
ocidentalização da cultura caminha a par com o desenvolvimento urbano, comercial e a necessidade de "letrados" para darem andamento 1 burocrático às estruturas de poder formadas em torno da Igreja e do Estado Moderno.
\end{abstract}

De um lado, o intelectual foi domesticado no contexto das universidades ligadas à Santa Sé; de outro, com a emergência do jesuitismo, seu aprendizado passou pelo processo de organização e planejamento de estudos num espírito de obediência — era o sentido da ratio studiorum de 1586.

No século XIX, a introdução da técnica e a ampliação da divisão do trabalho, com o desenvolvimento do capitalismo, levaram à necessidade da universalização do saber ler, escrever e contar. A educação já não constituía ocupação ociosa, e sim uma fábrica de homens utilizáveis ${ }^{1}$.

Hoje em dia a preocupação maior da educação consiste em formar indivíduos cada vez mais adaptados ao seu local de trabalho, porém capacitados a modificar seu comportamento em função das mutaçóes sociais. Não interessam, pelo menos nos países industrialmente desenvolvidos, operários embrutecidos, mas seres conscientes de sua responsabilidade na empresa e perante a sociedade global $^{2}$. Para tal, constitui-se um sistema de ensino que se apresenta com finalidades definidas e expressas.

Porém, se esse é o objetivo do sistema de ensino, insere-se nele um corpo professoral encarregado de transmitir o saber e mais ainda preocupado em inserir-se na sociedade, em ter reconhecimento oficial, êxito no magistério enquanto 
"carreira", utilizando para isso os diplomas acreditativos possíveis, numa sociedade em que, segundo Max Weber, o diploma substitui o direito de nascença.

A realização de tais objetivos pressupóe a existência de uma "burocracia pedagógica" com objetivos definidos ante a sociedade global, no entanto nem sempre os predominantes.

O sistema burocrático estrutura-se nas formas da empresa capitalista como também na área da administração pública; seu papel essencial são organização, planejamento e estímulo. O sistema burocrático estrutura-se em nível de cargos, que por sua vez se articulam na forma de "carreira", em que diploma acreditativo, tempo de serviço e conformidade às regras constituem precondições de ascensão. Seu modo de recrutamento e sistema de promoção são definidos por ela como sigilo, como mecanismo de comunicação intraburocrático, diluído nas diversas áreas de competência.

Um dos aspectos estruturais do sistema de educação burocrático é que os usuários não controlam de modo algum a gestão dos fundos que dedicam à coletividade. A estrutura burocrática do ensino no âmbito nacional desenvolve-se em três níveis:

- $\quad$ organização pessoal;

- programas de trabalho;

- inspeçóes e exames.

No que se refere ao pessoal, o burocrata da educação está separado dos meios de administração como o operário dos meios de produção, o oficial dos meios de guerra e o cientista dos meios de pesquisa.

O pessoal docente no sistema burocrático pode ser recrutado por concurso de títulos e provas, contratado a título precário, cujo nível de vencimento dependerá do número de aulas atribuídas por escolha fundada em pontos obtidos, a critério das secretarias de Educação.

Pode-se dar o caso de docente contratado a título precário e estabilizado no cargo por decreto, em obediência à exigência constitucional.

A ascensão do docente na carreira não depende da verificação dos resultados obtidos a longo prazo por ele sobre seus alunos. Portanto, os critérios de eficácia ou valor são desprezados e o de conformidade (aprovaçáo nos exames, provas), supervalorizados ${ }^{3}$.

O exame, mais que o programa, define a pedagogia do docente. O objetivo que a pedagogia burocrática lhe propóe não é o enriquecimento intelectual do aluno, mas seu êxito no sistema de exames. 
O melhor meio para passar nos exames consiste entáo em desenvolver o conformismo, submeter-se: isso é chamado de "ordem". Logo, colocam-se três objetivos ao docente: conformidade ao programa, obtençấo da obediência e êxito nos exames (LOBROT, 1966). A escola conduz a um condicionamento mais longo num quadro uniforme e máxima divisão do saber, que não visa à formação de algo, mas sim a uma acumulação mecânica de noçôes ou informaçôes mal digeridas. Se na Europa ou na América Latina o professor tende cada vez mais a responder a controles burocráticos, nos Estados Unidos as associações de pais, indústrias, grupos exercem pressōes para que se ensinem determinadas coisas com um tipo de orientação definida. Essa interiorização da burocracia, Alexis de Tocqueville no século XVIII e Riesman no século XX consideravam uma das características da cultura norte-americana.

A comunidade de pais encontra no controle burocrático a melhor garantia contra quaisquer tendências desviantes do professor ao saber, que é severamente controlado, julgado e regulamentado.

É nos níveis mais inferiores de ensino que a comunidade de pais tem maior peso. Quando a origem social dos alunos é pobre, o controle do vértice sobre a escola é ligado ao controle pela base na forma de conselho ou comunidade de pais. Quando o extrato social original dos alunos e professores é alto, por exemplo em nível universitário, o controle burocrático de topo satisfaz.

Há uma ambivalência em relaçáo à figura do professor: de um lado, é desprezado como "servidor da comunidade"; de outro, encarado como portador do saber absoluto, é criticado por não fazer sentir todo o peso de sua autoridade sobre o aluno. O público gosta da burocracia, quer ver seus filhos enquadrados, condicionados, como única condição de atingir a fase "adulta".

Uma escola fundada na memorização do conhecimento, num sistema de exames que mede a eficácia da preparação, nada provando quanto à formação durável do indivíduo, desenvolve uma pedagogia "paranoica", estranha ao concreto, ao seu fim. Quando falha, "interpreta" esse evento como responsabilidade exclusiva do educando.

Uma minoria de jovens pertencentes a camadas superiores da classe trabalhadora, ou pequenos funcionários, não frequenta o secundário e realiza-se em profissōes que exigem uma formação profissional específica. Assemelha-se à alta burguesia, que não se preocupa com a promoção social de seus filhos, oferecendolhes mais lazeres e liberdade, condiçôes de apreensão de um autêntico conhecimento. Enquanto isso, a pequena burguesia quer "subir", e os trabalhadores estão determinados a "sofrer" uma escola que não toma em conta suas aspirações. Esse contingente às vezes perfaz $80 \%$ da população.

No âmbito microescolar, encontramos na escola uma burocracia de staff (diretor, professores, secretário) e de linha (serventes, escriturários, bedéis). Os relacionamentos staffe linha variam muito com o grau de escola: se médio ou superior. 
Atualmente, efetuou-se no Brasil uma conjunção dos níveis primário e médio, tendendo à escola "unificada", que não deixou de criar problemas de "áreas de competência" entre o staff: quem dirige a escola unificada, o diretor do antigo primário ou do secundário?

Em suma, na escola como organização complexa se articulam as várias instâncias burocráticas enunciadas anteriormente, incluindo a inevitável Associação de Pais e Mestres e o aluno, objeto supremo da instituição, conforme o tom dos discursos solenes em épocas não menos solenes.

O corpo de professores procura manter sua legítima esfera de autoridade sem intromissōes "estranhas". É unânime na recusa à interferência dos pais no seu trabalho, pois isso pode prejudicar sua posiçâo de autoridade e sujeitá-los a controles por elementos estranhos ${ }^{4}$.

Nas suas relações com o diretor, a expectativa de comportamento dos professores é que recebam apoio desse diretor, seja em relaçáo a alunos, seja em relação aos pais de alunos. Funciona o princípio de que nenhum professor deve criticar o colega ante terceiros, especialmente alunos.

O diretor, por sua vez, funciona como mediador entre o poder burocrático da secretaria e a escola como conjunto; sofre pressão dos professores no sentido de alinhar-se com eles, dos alunos para satisfazer reclamos racionais ou não, dos pais para manter a escola no nível desejável pela "comunidade". Tem de possuir as qualidades de um político, algum senso administrativo, ser especialista em relações humanas e relatórios oficiais.

O pessoal de linha está diretamente subordinado ao diretor. Pode ser utilizado como meio de controle do corpo professoral, pelos controles das "conversas" de corredor e de "sala de professores", como também, se o diretor for do tipo "ausente", ter em suas máos o controle da "docilidade" dos alunos por meios informais, assegurando o bom andamento da instituição.

O pessoal de linha administrativa enfatiza algumas singularidades do comportamento burocrático, especialmente evitar a discussão pública de suas técnicas. Os despachos de "processo" são sonegados ao interessado enquanto não se der o chamado "despacho final" no citado processo. Burocracia administrativa entende-se como certa adesáo a regras — atividades/meio —, tendo em vista fins determinados. No entanto a disciplina, definida como adaptação a regulamentos, não é encarada como adaptação a finalidades precisas, mas constitui um valor básico na estrutura burocrática. Esse deslocamento das finalidades originais que se dá no processo burocrático determina alto nível de rigidez e incapacidade de ajustamento a situaçôes novas. Daí a ênfase no formalismo e o exagero no ritualismo burocrático nos estabelecimentos de ensino, no nível administrativo. 
A estrutura de "carreira" leva o funcionário a adaptar seus pensamentos, sentimentos e açóes nessa perspectiva, o que o induz à timidez, ao conservadorismo rotineiro e ao tecnicismo.

A burocratização desenvolve a despersonalização de relações entre burocracia e público, funcionários de secretaria escolar e o estudante. Ela desenvolve a tendência do burocrata a concentrar-se nessa norma de impessoalidade e a formar categorias abstratas, criando conflitos nas suas relaçóes com o público, pois os casos peculiares individuais são ignorados, e o interessado, convicto das peculiaridades de seu problema, opóe-se a um tratamento impessoal e categórico.

$\mathrm{O}$ comportamento estereotipado do burocrata não se adapta às exigências dos problemas individuais. $\mathrm{O}$ tratamento impessoal que ele confere a assuntos de grande significado pessoal para a parte interessada (aluno, professor) leva-o a ser visto como "arrogante", "insolente".

Tudo isso é coberto de uma grande capa de dramaturgia. O que significa isso? A dramaturgia, o culto da aparência, dos gestos, tem valor legitimado na estrutura burocrática. Da mesma maneira que a bata branca do médico ou do professor mostra que ali há alguém de limpeza irrepreensível, a régua de cálculo do engenheiro mostra alguém altamente especializado e "preciso". O talento dramático tem cada vez mais importância na função hierárquica, qual seja, do diretor severo, porém benevolente, do inspetor rígido e ao mesmo tempo assíduo tomador de cafezinhos na diretoria, além de assinante regular do célebre Livro de Termo de Visitas da Escola, como comprovante de que passou por lá...

Há um conceito segundo o qual os ocupantes de posiçóes hierárquicas são os mais capacitados, os mais trabalhadores, os mais indispensáveis, os mais leais, fidedignos e os mais autocontrolados; em suma, os mais justos, honestos e imparciais. Também se visualiza que uma pessoa muito ocupada é de importância incalculável para a burocracia e encara suas tarefas de maneira mais séria que as outras pessoas. É aconselhável para aqueles que querem vencer na estrutura burocrática carregarem as pastas debaixo do braço, mesmo quando saírem à noite ou pensarem em folgar nos fins de semana.

Acresce-se nas burocracias educacionais, escolares ou ministeriais que o sistema de status tem seu próprio dispositivo drarnatúrgico, incluindo insígnias, títulos, deferências e símbolos de grandeza material, como salas forradas de tapetes ou mobiliário luxuoso, ainda ditos filosóficos profundos como vê quem adentra a sala de um administrador universitário, por sinal também professor: "Quem sabe faz, quem não sabe ensina".

A conduta burocrática implica uma exagerada dependência dos regulamentos e padróes quantitativos, impessoalidade exagerada nas relaçóes intra e extragrupo, resistências à mudança, configurando os padróes de comportamento 
na escola encarada como organização complexa. Em suma, o administrativo tem precedência sobre o pedagógico.

\section{A escola como centro da reprodução das relações de produção}

Não há escola única. Há graus de ensino aos quais alguns têm acesso em nível decrescente quanto mais alto for o escaláo acadêmico.

A partir do primário, opera-se a divisão de duas redes de escolarização de classes, na medida em que o ensino primário:

- garante distribuição material, repartição dos indiví-uos nos dois polos da sociedade;

- garante função política e ideológica de inculcação.

A separação dos alunos em duas redes no ensino primário é o meio e princípio do funcionamento. Efetua-se no interior da escola primária: uma em direçâo acadêmica, outra em direção profissional. Uma rede é "primária profissional", e a outra, "secundária superior". O prolongamento da escolaridade obrigatória reforça o processo. A generalização da escolaridade obrigatória "única" é a generalizaçẫo da divisão. A inculcação ideológica dá-se por meio das várias formas de "saber", "verdade", "cultura", "gosto"s.

$\mathrm{Na}$ rede escolar, o culto da arte, ciência pura, profundidade filosófica, sutilezas psicológicas são formas de inculcação vinculadas a orientar a ação do educando conforme as normas de direito, políticas hegemônicas, sendo representadas como deveres.

A inculcação não se dá apenas pelo discurso, mas também mediante práticas de exercícios escolares em que a nota equivale ao salário, recompensa pelo trabalho realizado. Da mesma maneira que o mercado do trabalho é regalado pela competição, no interior da escola ela é cultuada nos sistemas de promoção seletivos. O aluno é obrigado a estar na escola e é livre para decidir se quer trabalhar ou não, ter êxito ou não, como o indivíduo é livre ante o mercado de trabalho.

As práticas do ritualismo escolar - deveres, disciplinas, punições e recompensas - constituem o universo pedagógico. A escola realiza com êxito o processo de recalcamento de pontos de vista opostos aos hegemônicos, e essa sujeição condiciona a inculcação. $\mathrm{O}$ trabalho é vagamente valorizado como artesanato, o processo histórico é reduzido a um conjunto de guerras, datas e nomes cuja finalidade principal é reduzir à insignificância o significativo: dimensões sociais do histórico ou sua temporalidade. Veja-se a dificuldade em convencer os historiadores de que o presente também é história. 
O aparelho escolar contribui para a reproduçáo da qualidade da força de trabalho, porque transmite saber e regras de conduta (ler, escrever e contar) e tem um destino produtivo.

Os alunos da rede escolar recebem também conteúdos científicos. Eis que o processo de escolarização contribui para a reprodução das condiçóes materiais de produção, uma vez que a produção social é uma transformação material da natureza, supondo o conhecimento objetivo sob as mais variadas formas.

Todas as práticas escolares estão a serviço da inculcação, que pressupóe "técnicas", "métodos" apropriados. A técnica escolar neutraliza os conteúdos de inculcação e os de saber positivo homogeneizando-os, na medida em que são ensinados como regras escolares.

O conhecimento escolar é usado no quadro de problemas surgidos da prática escolar com objetivos definidos: dar notas, classificar e sancionar os indivíduos. Isso porque há uma separação entre as práticas escolares e as práticas produtivas em geral. A separação escolar é chave na determinação do papel no conjunto de relações da sociedade atual. Isso é por conta da divisão entre o trabalho material e o intelectual, entre teoria e prática. Toda escolarização é por sua natureza conservadora, pois é ela quem legitima a separaçáo entre a consciência e a prática.

A escola é regida pelo princípio da contradição e não são categorias como "psicologia do escolar", "norma", "anormal", e sim categorias como "inculcação", "submissão", "recalcamento" que podem explicar alguns dos fenômenos que ocorrem nas estruturas escolares.

Como aparelho ideológico, a escola primária reflete uma unidade contraditória de duas redes de escolarização. A escola favorece os favorecidos e desfavorece os desfavorecidos, e o princípio disso está na diferença social da família.

Trata-se de se perguntar a cada indivíduo dado como ele passou sua infância pré-escolar, ela como determinante de sua escolaridade individual ulterior. As classes sociais não podem ser pensadas a partir dos indivíduos. Elas não se reduzem às propriedades sociais características de cada indivíduo. Essa visão atribui importância à família, lugar material da primeira educação. A explicação é regressiva, cronológica, individual.

Essa cronologia família, escola primária, ginásio ou não só existe do ponto de vista do indivíduo. Na realidade, família, escola primária, ginásio etc.:

- $\quad$ preexistem ao próprio indivíduo;

- coexistem simultaneamente;

- $\quad$ mantêm relações necessárias entre si. 
O professor está a serviço do aparelho escolar, não de sua classe. À falta de base, um nível de ensino remete ao imediatamente inferior e este à família, esquecendo que há duas redes em virtude da relação social de produção. Se há famílias providas e desprovidas é porque há duas classes. O funcionamento do conjunto do aparelho escolar e o lugar da escola primária no interior do aparelho escolar são definidos na sua função de reprodução das relaçóes sociais de produção.

Para Marx, as relaçóes sociais de produção são a combinação social das forças produtivas, a maneira pela qual os instrumentos de produção e o próprio trabalho produtivo se repartem socialmente entre os vários agentes da produção. $\mathrm{O}$ essencial é a relação de propriedade. Daí as relaçóes sociais da produção capitalista se definirem pela separação entre trabalho produtivo e os meios de produção, exploração do trabalho pelo capital.

O operário reproduz-se enquanto tal na medida em que náo tem elementos para acumular, mas somente para reproduzir sua força de trabalho. Essa reprodução pode originar-se por intermédio da industrialização da agricultura, empobrecimento das classes médias.

O aparelho escolar tem seu papel na reprodução das relaçóes sociais de produção quando contribui:

- $\quad$ para formar a força de trabalho;

- para inculcar a ideologia hegemônica, tudo isso pelo mecanismo das práticas escolares;

- para reprodução material da divisão em classes;

- para manter as condiçóes ideológicas das relações de dominação.

O aparelho escolar impõe a inculcação ideológica primária e é seguido pelos diversos aparelhos: televisão, publicidade, seitas etc.

A escola inclui, na forma de rudimentos, técnicas indispensáveis à adaptação ao maquinismo, em geral na forma preparatória.

$\mathrm{Na}$ família camponesa fundada na exploração agrícola em comum, a escola é considerada tempo perdido; não há escola de agricultura. O que aparece com esse título é escola para exploração agrícola capitalista.

A escola pode ser aparelho ideológico segundo estágios do modo de produção capitalista na sua combinaçẫo concreta no interior de cada formação social capitalista.

A escola não cria a divisão em classes, mas contribui para essa divisão e reprodução ampliada. 
A reprodução ampliada das classes sociais comporta alguns aspectos:

- A reprodução ampliada dos lugares que ocupam os agentes. Esses lugares designam a determinação da estrutura sobre a divisão social do trabalho;

- A reproduçáo (distribuição) dos próprios agentes entre esses lugares. Aí intervém ativamente na reprodução dos lugares das classes sociais. Há uma reprodução das classes sociais e pela oposição de classes, em que se move a reprodução ampliada da estrutura, inclusive das relaçóes de produção que presidem o funcionamento dos aparelhos ideológicos.

Os aparelhos ideológicos não criam a ideologia; inculcam a ideologia dominante. Não é a Igreja que cria ou que perpetua a religião; é esta que cria e perpetua a Igreja, diferentemente do que pensava Max Weber.

A análise do fetichismo da mercadoria ultrapassa os aparelhos ideológicos. Uma "empresa" é um aparelho no sentido de que há divisão social do trabalho em seu interior. A organização despótica do trabalho define as relaçôes politicas e ideológicas concernentes aos lugares das classes sociais no conjunto da estrutura. Há mecanismos para a reprodução de lugares e agentes; daí a insanidade em falar de ascensão social ou mobilidade social.

Dá-se a reprodução dos agentes. A "qualificação" é uma qualificação-sujeição, não é somente qualificação técnica do trabalho. A empresa é um aparelho distribuindo seus agentes no seu interior. As classes capitalistas não são castas escolares. A relaçáo escola-aparelho econômico continua a exercer sua açáo durante sua atividade econômica: isso se chama pudicamente formação permanente.

Não é a escola que faz com que sejam principalmente camponeses a ocuparem os lugares suplementares de operários. É o êxodo dos campos, acompanhando a reprodução ampliada da classe operária, que desempenha o papel da escola;

- Trata-se de uma distribuição primeira dos agentes, ligada à reprodução primeira dos lugares das classes sociais: é ela que designa para este ou aquele aparelho, para esta ou aquela série entre eles, e segundo as etapas e as fases da formação social, o papel respectivo que eles assumem na distribuição dos agentes ${ }^{6}$.

As organizaçóes complexas controlam e domesticam as forças sociais. Elas codificam, centralizam. Essa apropriação pela organização da existência, sob todas as formas, é realizada também pela destruição e desintegração, eliminando as forças que se opóem à sua expansão. 
Atrás do discurso da "racionalidade" nessa luta, a organização abriga-se para legitimar sua empreitada e desqualificar uma realidade que ela mutila.

Taylor, no que tange à organização industrial, Lenine, no que se refere à organização política, e Clausewitz, para a organização militar, são os fundadores de uma teoria que eles dominam a partir de seu status de chefes. A organização científica necessita de pais "místicos" para assegurar sua fundamentação.

As organizaçóes são, acima de tudo, produtos historicamente dados, e não "sistemas fechados" a-históricos, como pensa Crozier. Pretendendo romper com o passado, criticando acerbamente as instituiçóes tradicionais, a teoria organizacional procura uma ruptura "epistemológica". Essa ruptura tem como função proibir quaisquer comparaçôes entre instituiçôes tradicionais e organizaçóes modernas. Nessa imagem de organização, encontram-se estocados mitos, fábulas e lendas, um universo fantasmagórico mais ou menos discretamente camuflado que subsiste na base do discurso organizacional.

As organizações políticas, como as industriais, reforçam a área do imaginário. $\mathrm{O}$ tom é mais ou menos severo, pois, na iminência da tragédia, a traição ameaça o herói!

A escola tem um papel nessa mascarada organizacional, operando as variaçóes mais amplas, mediante os papéis de mestre, aluno, burocrata administrador. O asilo inventa a loucura ao sabor de suas conveniências pessoais.

O que se esconde atrás da representação de racionalidade organizacional? Marx ensinou-nos a ver que atrás do espetáculo da circulação de mercadorias se escondia o trabalhador mutilado; o fetichismo mercantil esconde o sentido da organização. Ela é a base mais apropriada à imaginação moderna. Isso constitui uma das condiçóes do desenvolvimento das organizaçóes.

Centro da tensão é ao mesmo tempo da transferência: o tempo presente transcorre em função de satisfaçóes futuras. A organização burocrática exerce a ditadura do signo, na qual as palavras-chave que a designam são contabilidade, plano, programa, controle.

A organização complexa apresenta-se como uma forma à qual tudo deve se submeter ${ }^{7}$.

Nos supermercados, nenhum objeto é percebido na sua imediatez: tudo é empacotado, conservado, etiquetado. Do produto somente percebemos a representação, fotografia, legenda, desenho. Os corpos materiais dissolvem-se em corpos de signos; são elementos num único texto.

Idêntico processo de coisificação opera-se com o elemento humano. Dirigir homens é como rotular mercadorias, é manipular signos. 
As organizações complexas "traduzem" o real numa linguagem simples, transcrevem os corpos em signos. Realizada a operação, o que sobrou do corpo original? Ele desaparece na nova representação. A organização toma como interlocutor o corpo que ela produziu; ela define, para nós, o emprego do tempo e do nosso corpo. No fim do processo, o corpo nada mais é do que um signo num conjunto de signos que formam as malhas organizacionais.

A organização apropria-se de nosso corpo de tal forma que qualquer ruptura nos aparece como uma autorruptura. É aí que a adesão à organização encontra um de seus fundamentos; o corpo, que adere à organizaçáo visualizando a possibilidade de uma ruptura, reage com alta carga de ansiedade. Controladores e controlados, engajados no mesmo processo, participam de uma comunidade de destino: a organização da racionalidade.

A análise da violência e do sacrifício são inerentes à estrutura organizacional.

A organização realiza um processo concomitante: destruição e unificação. O homem dividido na execução de suas tarefas parceladas, isolado no seio da grande metrópole, é reagrupado no interior das imagens organizacionais.

\section{Conceito de taylorismo: fisiologia do corpo dividido}

A organização significa um combate contra a entropia.

Mauss (s.d.b) conta a história de um mito tsimshian em que uma princesa dá à luz uma petite loutre miraculosamente; dirige-se com a criança à cidade de seu pai, o chefe. Apresenta-a a todos e pede para não a matarem caso a reencontrem pescando na sua forma animal. Mas ela se esqueceu de convidar um chefe. $\mathrm{O}$ chefe e a tribo esquecida encontram no mar petite loutre, que tinha na boca uma grande foca, e matam-na. $\mathrm{O}$ grande chefe procura-a e encontra-a no seio da tribo esquecida. Seu chefe desculpa-se, pois não conhecia petite loutre. Sua mãe, a princesa, morre de melancolia, e o chefe, culpado involuntariamente, encaminha ao grande chefe todos os tipos de presentes como expiação.

Os reis esquecem-se de convidar outros chefes para seu casamento, os criminosos sempre deixam uma pista. Luta-se em todos os níveis contra a entropia: o mito tsimshian mostra que uma perturbação no sistema conduz à morte! É o que, em linguagem moderna, é a sabotagem, a pane que as organizaçóes modernas tentam conjurar. $\mathrm{O}$ equilíbrio camufla o desequilíbrio.

As organizações mantêm-se pela transmissão de energia e sua conversão em trabalho. A reprodução da força de trabalho dá-se em períodos de desequilíbrios sociais; por exemplo, nas migraçóes rurais-urbanas, em que multidóes sem trabalho se concentram na periferia das grandes cidades; ou em migraçóes operárias de países estagnados para áreas de "crescimento", como portugueses, 
espanhóis, argelianos, turcos na Europa. Como fonte de energia, o trabalhador é vítima do processo de dilapidaçóes e desgastes, e a organização que canaliza sua energia o integra no movimento de deslocamento e desintegração. Daí se verifica que a transformação de energia em trabalho só é possível por meio dos desequilíbrios provocados pelas organizaçóes.

A eficiência do esquema centralizador é simbólica. Nesse sentido, cabe à organizaçáo a produção do que a diferencia perante o mundo. A sociedade consumista insere-se no campo da simulação diferencial. A organização unifica a produção, representação da diferença. A dramaturgia converte-se na finalidade principal das organizaçôes: congressos, paradas, desfiles, delegaçóes recebidas com grandes pompas, banquetes, publicidade intensiva. A organização produz o espetáculo. A distinção entre produção e representação desaparece. A organização deve produzir diferenças simbólicas ou extinguir-se.

Assim, o nazismo, pela representaçáo de massas, desmoraliza os oposicionistas reais ou potenciais. Tanto o Tennessee Valley Authority, como as grandes obras do Rio Dniepre, não só justificam uma organização centralizada, como também criam condiçôes para o lirismo organizacional.

A estrutura de pirâmide impóe sua ordem, a "eficiência nasce da hierarquia", seja a pirâmide familiar, política, educacional. A organização é o grande elemento mediador entre "mim" e o "outro". O medo do isolamento dá-se na medida em que a estrutura piramidal tem os meios para assegurar o monopólio das relaçôes entre os homens. A organização centralizada e unitária constitui o grande refúgio; ela "domestica" a energia sem direção. Náo é por acaso que as organizaçôes mais "eficientes" são aquelas nas quais predomina um sexo só: por exemplo, a Igreja. Ela garante a vida de seus membros; nada é possível sem ela. A autonomia inexiste; só há o dilema: inserir-se na organizaçáo ou desaparecer. Por isso ela acentua a retórica da integração. $\mathrm{O}$ sindicato para Tannenbaum, a comunidade de Lloyd Warner e a corporação de Durkheim e Elton Mayo aparecem como os "possíveis integracionistas" num universo dividido.

$\mathrm{Na}$ realidade, a oposição segurança-insegurança, integração - exclusão é artificial. Assim, a revolução industrial organiza o novo modo de produção, ao mesmo tempo em que divide o homem num conjunto de tarefas parceladas.

Embora March e Simon argumentem que no bojo da teoria organizacional não há lugar para a coordenação, participam do delírio organizacional racionalista que não quer enxergar as organizaçôes como instâncias do imaginário também. A direção exclui, como os padres sacrificam. O centro funciona como um dado que deve ser "escotimizado" — também na teoria dos sistemas isso se dá. No entanto, constitui peça fundamental.

A organização burocrática complexa não explicita a necessidade do "centro", porém o não-necessário se institui como pivô da organização. Tal "estra- 
nheza" faz parte também de certa concepção burocrática de socialismo, em que o Estado deva desaparecer progressivamente, e, no entanto, ele domina em toda a sua amplitude! O poder é apreendido como um escândalo. A coordenaçáo apropria-se do espaço reservado ao fantasma piramidal. As relaçóes instituídas apresentam uma sucessão de níveis hierárquicos em que cabe ao superior uma zona reservada e o subalterno não pode entrar.

O pai que é proprietário do corpo da mulher, interdito aos filhos, o senhor feudal que se apropria da terra, o professor que dispóe soberanamente de um campo dos conhecimentos. O usufruto dessa situação pressupóe a aceitação do papel de pai, proprietário, chefe, professor. Da mesma maneira que o senhor exercia poder absoluto sobre suas terras, os detentores da informaçáo instalam um domínio confortável, como "na Régie Renault, com a introdução de uma nova máquina, só o contra-mestre pode compreender o funcionamento" (MOTHE, [s.d.], p. 10).

O sistema cultural assiste à ruptura entre a palavra sagrada e a profana. Náo é mais Deus que dispóe do monopólio do verbo nem a Igreja de sua interpretação. A ciência ocupa hoje o lugar do verbo divino. A casta dos cientistas substituiu a hierarquia eclesiástica como elemento mediador entre a palavra superior e a coletividade humana.

O antagonismo "puro" e "impuro" encontra-se entre os chamados trabalhos "sujos" e "limpos", como nas relaçôes entre trabalho "manual" e "intelectual”. A organização, por intermédio de seus psicólogos industriais, afirma a possibilidade de vencer a impureza. Os esgotos podem ser transformados em matéria sã. A guerra "limpa" tecnologicamente definida coexiste com a "suja", rústica.

A eficiência da impureza consiste na delimitação das áreas do proibido. Os impuros são intocáveis, só podem ser destruídos. O nazismo significou a dominação totalitária dos puros sobre os impuros. Nas organizaçóes altamente burocratizadas, instituições totais, o impuro é segregado por obstáculos como muros altos, florestas, portas de ferro, como o demonstrou Goffman (s.d.).

Os contatos com o exterior são monopolizados pela direção. O subalterno não tem contato com os circuitos externos da empresa; só os responsáveis podem manter tais relacionamentos. Caso haja qualquer caso de espionagem industrial, os subalternos têm menor chance de sair-se bem que os elementos de staff privilegiados por seus contatos com o exterior, que amplia as possibilidades de manobras deles.

$\mathrm{Na}$ medida em que a organização burocrática delimita as zonas de impureza interna e externa, ela assegura certa dinâmica energética. $O$ funcionamento é garantido - como em algumas organizaçōes políticas - pela luta contra os sabotadores do interior e os inimigos do exterior. A empresa só evolui na luta contra as disfunçóes do mercado. Haverá relação entre o domínio do impuro pelas 
organizaçóes e o grau de sua eficiência? O nazismo, que definia como fim explícito reduzir as raças impuras, construiu organizaçôes burocraticamente estruturadas para atingir tais objetivos: SA, SS, KL. No entanto, o quotidiano mostrou uma constante preocupação em julgar o impuro. A impureza constitui o centro do discurso das organizaçóes industriais. É um dos temas favoritos da manipulação publicitária. Não há nenhum anúncio de detergentes que não avalize suas qualidades na cruzada contra o impuro. O bom funcionamento organizacional implica depuração periódica.

Paralelamente a esse processo, instaura-se o processo da construção de um imaginário, por mediação da organização, em direção a seus clientes. O campo publicitário organizacional apresenta um universo em que a organização se constitui como "prestação de serviços" e para a qual o "cliente" tem sempre razáo e manda. A organização é atenciosa e asséptica, benevolente com os caprichos da clientela. O desejo consiste em elemento fundante da conduta do cliente. Nada lhe é recusado, tudo é permitido; ele pode satisfazer-se na sua imediatez e plenitude. Ela substitui o espetáculo do lucro pelo da gratuidade. Para tal, constitui uma área em que o $\mathrm{dom}^{8}$ tem cidadania, pequenos bônus anexos às mercadorias, que possuem importância básica na definição da marca.

As adaptaçóes ao mercado, inerentes às organizaçóes lucrativas, se dáo ao lado de um processo de regeneração das mercadorias e serviços propostos à clientela. Quanto à mão de obra, o termo participação parece ter virtudes suficientes para ancorá-la à organização com muito mais firmeza que o servo à gleba!

A vida só é possível no processo organizacional. $\mathrm{O}$ imaginário enquadrado pela organização transforma-se num rutilante apelo burocrático, com todo o pathos de um ofício de repartição pública, imaginam os Sófocles amanuenses.

O fato é que a mão de obra sai da empresa para entrar no sindicato burocratizado, frequenta a Igreja ou um partido, os dois estruturados em forma de pirâmide, com níveis de staffe linha, com regras rígidas interpretadas legitimamente por outros elementos treinados nesse mister, dispondo dos títulos reconhecidos. Em suma, o ritmo vital é regulado pela escola, exército, empresa, hospital, agência de viagens e, finalmente, pelo asilo.

Nas instituiçóes totais é um mesmo grupo de coparticipantes que controla tudo sob a mesma autoridade, conforme um plano racional geral, não importa se ele é elaborado pelo staff do presídio, do manicômio, do convento ou do colégio interno.

Nessas instituiçóes, há o grupo maior cuja atividade fica confinada aos limites da organização total, e o pessoal de staff, que mantém horário de oito horas de trabalho e contatos com o exterior. São características as barreiras "interno" e staff, com estereótipos concomitantemente negativos ou agressivos em relação ao "outro". Há um grande hiato entre eles, grande distância social. 
Enquanto o operário recebe um salário e tem a liberdade de gastá-lo em qualquer ambiente, o mesmo não se dá com o interno das instituiçóes totais, que assumem a "responsabilidade" por ele e exigem algum ou pouco trabalho. Geralmente, está incorporado a sistemas de pequenos pagamentos cerimoniosos como, por exemplo, a raçáo semanal de fumo ou presentes de Natal que motivam os doentes mentais a continuarem em suas ocupaçóes. Em algumas prisões, navios, campos de cortes de árvores, é possível alguma poupança "forçada"; o indivíduo recebe o que lhe é devido após cumprir a pena.

As instituições totais desenvolvem mecanismo de despojamento e mortificação do "ego": decisóes autônomas são eliminadas mediante a programação coletiva das atividades diárias.

A estrutura de autoridade é escalar; ela articula-se com o aspecto informal definido como regras do local que definem formalmente níveis de proibiçóes. Em troca, o staff oferece recompensas e privilégios, que se constituem em modos peculiares às instituiçóes totais. Receber visitas, fumar um cigarro, o dia de folga sua negação por qualquer transgressáo cometida aos regulamentos — assume um aspecto vital no quotidiano do interno da instituição total.

No entanto, nas instituições totais é possível que se dê este processo: os guardas não comunicam infraçóes aos regulamentos, transmitem informaçóes proibidas aos presidiários, negligenciam as exigências elementares de segurança e aliam-se aos presidiários em críticas francas aos funcionários da alta burocracia. Muitos podem ter em si uma ambivalência básica em relação aos detentos sob sua guarda: embora condenados, muitos criminosos representam "sucesso", em termos de um sistema mundano de valores (alto prestígio, notoriedade e riqueza), e o guarda mal remunerado poderá sentir prazer em associar-se a alguém tão "famoso".

Pode dar-se a corrupção pela instituição total mediante a reciprocidade no caso em que o controle da docilidade do presidiário resida menos nas sançóes negativas, o que representa encargos para a administração da prisão, que na consecução de certo nível de cooperação voluntária do presidiário. Em troca, infrações secundárias aos regulamentos são ignoradas.

\section{Conclusões}

No interior do sistema social, as instituiçóes educacionais e seus sacerdotes, os professores, desenvolvem um trabalho contínuo e sutil para a conservação da estrutura de poder e, em geral, da desigualdade social existente. Duas são as principais funçóes conservadoras atribuídas à escola e aos professores: a exclusão do sistema de ensino dos alunos das classes sociais inferiores e a que definimos 
como socialização à subordinação, isto é, a transmissão ao jovem de valores compatíveis com o seu futuro papel de subordinado?

Examinemos a primeira conclusão. Uma frase repetida continuamente pelos sociólogos liberais é que a escola constitui o mais expressivo canal de ascensão social. Tal proposição é exata na medida em que "a atribuição da posição social de hoje é cada vez mais ligada ao sistema de escolaridade". Mas é errada e mistificadora, se entender-se que a escola favorece ou promove a mobilidade social. Eis que há fortíssimos obstáculos que impedem a "inteligência" e a "capacidade" de manifestar-se, privilegiando mais a cumplicidade com o sistema como critério de ascensão social.

É importante lembrarmos que a família conserva grande parte de sua importância como base inicial da seleção social dos indivíduos; ela transmite ao herdeiro, ao filho, não somente o capital financeiro, mas também o capital cultural. Esse capital cultural tem sua legitimidade definida por intermédio dos títulos escolares.

O relevante é que se desenvolve num sistema de ensino pré-universitário unificado, em que o sistema escolar convence o aluno de origem popular de que é necessário competir para atingir altos escalóes, e de que "seu destino social depende antes de mais nada de sua natureza individual" (BOURDIEU, 1966, p. 325-347). Paralelamente a escola desenvolve o processo de "socialização", ou seja, da aceitação do existente como o desejável. A dificuldade do corpo professoral em adaptar-se às mudanças socioculturais pode implicar a sua visualização não como um corpo que reproduz valores dominantes, mas sim defensor de um patrimônio valorativo superado, qual seja, de vestal da classe média.

\section{Notas}

1. O taylorismo tem a finalidade de eliminar o poder de decisão do operário, transformá-lo numa máquina. A organização moderna é a instituiçấo em que se realiza a relação de produçãa que constitui a característica de todo o sistema social. Trata-se do mecanismo de exploração e rege-se pela coerção e manipulação. A substância da organização não é um conjunto funcional, mas sim a exploração, o boicote e a coerção.

2. Para Simon, a hierarquia é necessária para alcançar um fim comum; ela tende a tornar-se mais rígida quanto mais complexa é a organização. Sustenta-se que, da mesma maneira como no mecanismo de mercado, o fim de todos coincide com o de cada um. Acha-se como pressuposto certo tipo de racionalidade que os utilitaristas do século passado sustentavam como universal, no entanto os fins são formulados pela cúpula; a teoria da organização pretende não discutir o problema central do poder. Isso explica também o êxito do estudo referente aos "pequenos grupos", nos quais o conformismo constitui fonte de felicidade. 
3. O processo define a hegemonia do autoritarismo no âmbito escolar. A palavra autorizada é do mestre, e ela mesma é definida pelo programa e pelas instruções sobressalentes. O caderno funciona como registro e permite a inspeção, o controle da conformidade. Os dispositivos audiovisuais permitem difundir programas pré-fabricados que correspondam a um discurso escolar estritamente subordinado à organização!

4. A convicção de que o prestígio profissional está progressivamente diminuindo é confirmada por pesquisas realizadas nos Estados Unidos, na Itália, na Alemanha, no que se refere a professores de nível ginasial, conforme Schefer (1969), especialmente.

5. O discurso sobre a produção reservado aos tecnocratas, o discurso sobre as relaçóes sociais reservado aos políticos, o discurso da mudança reservado aos revolucionários profissionais, o discurso sobre o sexo reservado ao Conselho Superior para a Educação Sexual, o discurso sobre o corpo de âmbito dos médicos!

6. Muitas pesquisas desenvolvidas em diversos países demonstraram que o excessivo contingente de alunos por classe é uma das maiores fontes de insatisfaçáo dos professores, conforme Schuh (1962). Nessa pesquisa, que envolveu 508 professores alemães, as maiores fontes de insatisfação provinham: do excessivo número de alunos por classe, do baixo prestígio social do ensino e da escassa possibilidade de carreira. Resultados idênticos no que respeita à França foram colhidos por Benjamim (1964). A Europa caracteriza-se na educação por um sistema de mobilidade cooperativo. Os alunos das classes inferiores são eliminados de diversas formas. $\mathrm{O}$ simples fato de a escola cujo recrutamento de alunos se estrutura nas classes média e alta estar próxima à habitação do aluno, formar classes pequenas, possuir material didático a singulariza ante os alunos das classes pobres. Há uma escola média para formação da classe dirigente, e outra técnica, sem possibilidade de chegar ao nível superior, para a classe operária. Isso fora teorizado por Botai (1941, p. 28).

7. Pré-requisitos necessários ao professor de inglês no início do século XVIII: "Ele deve ser: 1) membro da Igreja da Inglaterra, de vida e palavra austera, idade náo inferior a 25 anos; 2) dedicado à Santa Comunhão; 3) capaz de autodomínio de si e das paixões; 4) de caráter submisso e conduta humilde; 5) possuir bom talento didático; 6) bem informado dos princípios e fundamentos da religião cristâ, com capacidade para prová-lo ante o ministro da paróquia ou ao bispo mediante exame escrito; 7) possuir boa caligrafia e sólidos fundamentos nas matemáticas; 8) membro de uma família de ilibada conduta moral; e 9) contar com a aprovação do ministro da paróquia (sendo um fiel) antes de procurar autorização do bispo" (TROPP, 1957).

8. "O uso contínuo do conceito do dom ou dotes intelectuais constitui um pretexto para desviar o discurso das causas sociais das menores possibilidades de instrução que têm na Alemanha os filhos de operários, remontando-as a pretensas causas naturais" (DAHRENDORF, 1965, p. 29).

9. A insensibilidade ante a desigualdade social e seu papel no comportamento do aluno constitui também característica do ensino nos países desenvolvidos. Ver: Ulibarri (1967). 


\section{Referências}

BENJAMIN, R. L'univers des instituteurs. Paris: Minuit, 1964.

BOTAI, G. La carta della scuola. Milano: Mandadori, 1941.

BOURDIEU, P. L'école conservatrice. Revue Française de Sociologie, v. 7, p. 325-347, 1966. DOI: $10.2307 / 3319132$

DAHRENDORF, R. Arbeiterkinder an deutschen Universitaten. Tübingen: F. C. B. Mohr, 1965.

ESTABLET. L'école capitaliste en France. Paris: Maspero, 1971.

FERRER, F. La escuela moderna. Montevidéu: Solidariedad, 1960.

GOFFMAN, E. Presídios, manicômios e conventos. São Paulo: Perspectiva, [s.d.].

LOBROT, M. A pedagogia institucional. Lisboa: Iniciativas Editoriais, 1966.

MARCELO, D. Le vestali della classe media. Bologna: IL Mulino, 1972.

MAUSS, M. Oeuvres. Paris: PUF, [s.d.a]. 3 v. Sociologie et anthropologie. Paris: PUF, [s.d.b].

MOTHE, D. Militant chez Renault. Paris: Seuil, [s.d.].

SCHEFER, G. Das Geselleschaftsbild des Gymnasiallehrers. Frankfurt am Main: Suhrkarnp, 1969.

SCHUH, E. Der Volksschullehrer Storfakto en in Berufsleber und ihre Ruckwiekung auf die Einstellung in Beruf. Berlim: H. Schrodel Verlag, 1962.

THOMPSON, V. As modernas organizaçôes. Rio de Janeiro: Freitas Bastos, [s.d.].

TRAGTENBERG, M. Burocracia e ideologia. São Paulo: Ática, 1992.

TROPP, A. The school teacher. Londres: Heinernann, 1957.

ULIBARRI, H. Teacher awareness of sociocultural differences in multicultural classrooms. In: KEACH, E.T. Education and social crisis. Nova York: J. Wiley, 1967. p. 139-144.

\section{Nota de Apresentação}

\section{Doris Accioly E Silva ${ }^{1}$}

$\mathrm{O}$ artigo de Maurício Tragtenberg aqui republicado surgiu em coletânea de 1976, organizada por Walter E. Garcia, sob o título "Educação Brasileira Contemporânea: Organização e Funcionamento”. Foi posteriormente integrado ao livro de Tragtenberg Sobre Educação, Politica e Sindicalismo, pelas editoras Autores Associados e Cortez, em 1982. A mesma obra foi republicada pela Editora

\footnotetext{
${ }^{1}$ Universidade de São Paulo, Faculdade de Educação - São Paulo (SP), Brasil.
} 
Unesp, em 2004, como um dos títulos da coleção Maurício Tragtenberg, dirigida por Evaldo A. Vieira, que reúne a obra completa do autor. A trajetória do artigo inicia-se dois anos antes da criação do Cedes e da Revista Educação e Sociedade, dos quais Tragtenberg foi um dos fundadores. Pode-se dizer que muitas das concepçôes críticas que percorrem o artigo estarão presentes no nascimento da revista, como a preocupação em desvendar as artimanhas do poder burocrático e do mercado no universo das instituiçóes contemporâneas. Uma de suas contribuiçōes para a revista foi a necessidade de integrar as ciências humanas, a literatura, as várias esferas do conhecimento à compreensão da educação e da questão escolar. O problema da formaçáo dos professores e de sua organização estava no cerne das reflexões e práticas de Tragtenberg. A revista constituiria, em sua perspectiva, um permanente exercício nessa direção, inseparável das lutas dos trabalhadores pela apropriação do conhecimento como requisito de sua emancipaçáo. $\mathrm{O}$ momento político em que nasceram o Cedes e Educação e Sociedade guarda com o que vivemos hoje algumas semelhanças, a despeito de muitas diferenças. Uma profunda afinidade percorre ambos: a permanência da desigualdade social, dos privilégios, do autoritarismo. Agora, sob as vestes de uma suposta democracia. Daí decorre a profunda atualidade do artigo de Tragtenberg e da tarefa que propôs à revista Educação e Sociedade, que comemora 40 anos, e ao Centro de Estudos Educaçáo e Sociedade, criado em 1989.

Recebido em 04 de janeiro de 2018.

Aceito em 05 de fevereiro de 2018. 